\title{
International Capital Markets Structure, Preferences and Puzzles: The US-China Case*
}

\author{
GUGLIELMO MARIA CAPORALE \\ Brunel University, London, CESifo Munich and DIW Berlin \\ MICHAEL DONADELLI \\ Center of Excellence SAFE, Goethe University Frankfurt \\ ALESSIA VARANI \\ HEC Montreal
}

FEBRUARY 2014

\begin{abstract}
A canonical two country-two good model with standard preferences does not address three classic international macroeconomic puzzles as well as two well-known asset pricing puzzles. Specifically, under financial autarky, it does not account for the high real exchange rate (RER) volatility relative to consumption volatility (RER volatility puzzle), the negative RER-consumption differentials correlation (Backus-Smith anomaly), the relatively low crosscountry consumption correlation (consumption correlation puzzle), the low risk-free rate (risk-free rate puzzle) and the high equity risk premium (equity premium puzzle) in the data. In this paper, we show that instead a two country-two good model with recursive preferences, international complete markets and correlated long-run innovations can address all five puzzles for a relatively large range of parameter values, specifically in the case of the US and China. Therefore, in contrast to other IBC models, its performance does not rely on any financial market imperfections.
\end{abstract}

Keywords: Financial autarky, complete markets, long-run risk, anomalies JEL Codes: F3, F4

*Authors' emails: Guglielmo-Maria.Caporale@brunel.ac.uk; michael.donadelli@gmail.com; alessia.varani@gmail.com. We are grateful to Monica Billio, Max Croce, Pierpaolo Benigno, Nicola Borri, Andrea Moro and Christian Schlag for helpful suggestions. We also thank seminar participants at LUISS Guido Carli, Ca'Foscari University of Venice, Brunel University, Halle Institute for Economic Research. All errors are our own. 


\section{Introduction}

The international business cycle (IBC) literature of the last 20 years points out that the risk-sharing predictions of standard IBC models with complete markets do not match cross-country movements in consumption. Early studies show that a standard IBC model with complete markets encounters difficulties in matching international consumption and asset pricing data (Backus et al., 1994, 1995). In particular, it tends to produce international asset prices that are less volatile than the actual series. Even under a financial autarky regime, the level of international risk sharing generated by the model is unrealistically high. It turns out that the correlation between the RER and consumption differentials (Backus and Smith's (1993) correlation) is close to unity. In addition, in a scenario characterized by low RER volatility and high degrees of international risk-sharing the domestic and foreign consumption growth rates are highly correlated.

In a seminal contribution, Lewis (1996) suggests that high degrees of international risk-sharing might be generated by the non-separability of tradable and nontradable goods in the utility function employed in the model as well as by the presence of international complete markets (i.e. full risk-sharing). He concludes that both capital market restrictions and non-separability are required to explain the lack of international risk-sharing observed in the data. Overall, the international risk sharing mechanism embodied in this class of models gives rise at least to three international macroeconomic puzzles: i) the high volatility of the RER relative to the volatility of consumption (real exchange-rate volatility puzzle); ii) the negative correlation between RER and consumption differentials (Backus and Smith puzzle); iii) the low correlation of consumption growth across countries (consumption correlation puzzle) ${ }^{1}$ In addition, standard IBC models with complete markets and standard preferences do not address the equity premium puzzle, EPP, (Mehra and Prescott, 1985; Mehra, 2003) and the risk-free rate puzzle (Weil, 1989).

\footnotetext{
${ }^{1}$ For additional details see Bodenstein (2008).
} 
The international risk-sharing mechanism present in these models and its implications for the resolution of the various international macroeconomic and asset pricing puzzles have received considerable attention in the IBC literature, much of it addressing individual anomalies (Benigno and Thoenissen, 2008; Corsetti et al., 2008; Kollman, 2012; Hamano, 2013). Relatively little research, however, has focused on the joint resolution of these puzzles (Bodenstein, 2008; Colacito and Croce, 2013). Benigno and Thoenissen (2008) develop a standard IBC model with nontraded goods and incomplete markets. They show that under strong complementary between domestic and foreign tradables the model addresses the Backus-Smith puzzle. Similarly, Corsetti et al. (2008) argue that international financial markets are not developed enough to generate full risk sharing and show that standard IBC models with incomplete markets account for the Backus-Smith correlation. In particular, if there is a high level of complementary between exported and imported goods, then the model produces substantial movements in the RER as well as a negative correlation between the RER and relative consumption, and reduces the correlation between domestic and foreign consumption. However, these results are not robust to the introduction of a second trade asset (Benigno and Kukuc-Tuger, 2010). Kollman (2012) shows that the Backus-Smith anomaly can be explained by a simple IBC model in which a fraction of households cannot participate in the trading activity.

Bodenstein (2008) develops a two country model with complete asset markets and limited enforcement for international financial contracts where the ability to share risk depends on the degree of patience of the agents. He shows that, if agents are sufficiently impatient (i.e. markets are incomplete), the model addresses the RER volatility puzzle, the Backus-Smith puzzle and the consumption correlation puzzle simultaneously. Following Corsetti et al. (2008), Thoenissen (2011) shows that a standard IBC model with incomplete markets is able to solve the RER volatility puzzle, the RER persistence puzzle and the Backus-Smith anomaly. However, the success of the model heavily depends on the choice of the elasticity of substitution 
between domestic and foreign produced goods. In particular, the range of elasticity values that allows the model to address the macro-puzzles is very narrow. In line with these IBC studies, Hamano (2013) shows that market incompleteness (i.e. a partial risk-sharing environment) is crucial for the resolution of the consumption-real exchange rate anomaly.

There is an extensive debate in the literature on whether or not "financial autarky" and "one-bond world" regimes represent realistic financial environments and the international risk sharing mechanism is efficient. On the one hand, numerous international finance studies show that both developed and emerging capital markets have become largely integrated over the last two decades (Pukthuanthong and Roll, 2009; Bekaert et al., 2011; Volosovyvh, 2011; Donadelli, 2013: Ma and McCauley, 2013; among others). For example, Fitzgerald (2012) finds that financial risk-sharing among developed countries is nearly optimal. A higher degree of financial integration improves household consumption smoothing, that is, the consumers' ability to hedge against good or bad news (Jappelli and Pistaferri, 2011). On the other hand, some theoretical studies argue that a "financial autarky" regime or a "one-bond world" do not represent realistic financial environments. Heathcote and Perri (2002) conclude that an efficient international trading activity environment (i.e. international borrowing and lending opportunities) is important for the IBC. Kollman (2012) points out that international capital markets allow for an almost frictionless trading activity in a large variety of securities (e.g. equities, futures, options, CDS, bonds). Crucini (1999) and Santos Monteiro (2008) argue that standard incomplete markets models are problematic in that they are characterised by limited consumption risk-sharing both at the domestic and international level.

The aim of the present paper is to compare the international macroeconomic quantities and prices produced by an IBC model under a financial autarky regime with those produced by a model with international complete markets. In other words, we ask the question whether a limited international risk sharing environment is necessary to solve simultaneously the three classic international macroeconomic 
puzzles described in Bodenstein (2008). Our analysis is conducted by using a recently developed two country-two good model with recursive preferences, highly correlated long-run shocks and frictionless markets (Colacito and Croce, 2010). In our setup, capital markets are complete both domestically and internationally, and agents have preference for domestic goods. The choice of this model is due to several reasons: it reflects a period of increasing financial integration by assuming international complete markets, it can capture both the first and second moments of asset pricing, it accounts for consumption home bias, and it embodies a novel risk-sharing mechanism which does not rely on any financial market imperfections.

Our paper extends the IBC analysis on international risk-sharing in two main directions. First, we focus on US-China data over two different periods: i) the financial autarky regime which runs from 1972 to 1991 (when the stock market was first liberalised in China); ii) international complete markets from 1992 to 2009. Second, in the spirit of Bodenstein (2008), we aim to address the RER volatility puzzle, the Backus-Smith puzzle and the low consumption correlation puzzle simultaneously. We show that the employed two country-two good model with recursive preferences, long-run risk and complete markets can address the puzzles simultaneously even if there are no financial market imperfections. Third, we examine the robustness of the model and show that the results stand for a relatively large range of parameter values. In particular, changes in the RRA, IES, consumption home bias parameter and cross-country long-run shocks correlation do not alter the RER-consumption volatility ratio, the Backus-Smith correlation and the cross-country consumption growth correlation.

Our work is closely related to that of Bodenstein (2008), who focuses on the simultaneous resolution of the RER volatility, Backus-Smith and consumption correlation puzzles by employing an endowment economy. However, in contrast to Bodestein (2008), our setup does not require an inefficient risk-sharing environment (i.e. sufficiently impatient agents). In addition, it accounts for the relatively low risk-free rate and high equity risk premium (ERP) in the data. Overall, we show that 
a two country-two good model with recursive preferences, complete and frictionless markets, consumption home bias and correlated long-run shock accounts for three important international macroeconomics anomalies as well as two well known asset pricing puzzles. We stress that its performance is not affected much by changes in the parameter values.

The rest of the paper is organized as follows. Section 2 presents some stylized facts for China and the US. Section 3 outlines the model. Section 4 discusses the results. Section 5 concludes.

\section{On the US-China relationship}

\section{$2.1 \quad$ Why US-China?}

The debate on when China will overtake the US in terms of GDP is ongoing. At current growth rates, China will probably be the world's largest economy in the next decade. At present, the US and China account for almost one third of the world's GDP (33\% in 2012). Both goods and financial trade have increased sharply since during the mid 90's. Recent estimates suggest that China's GDP is almost double Japan's GDP and almost three times higher than the GDP of the UK, France and Italy GDPs.2 As for the Chinese stock market, this was closed for nearly half a century and reopened less than 25 years ago. In the late 1980s, China transformed many state-owned-enterprises into stock companies. The first stock market in the history of the People's Republic of China, the Shanghai Stock Exchange, opened on November 26, 1990. Shenzhen Stock Exchange opened on April 11, 1991 where, initially, only one class of shares (public A shares) were allowed to trade on Qualified Foreign Institutional Investor (QFII). This allows us to analyze two different international capital markets regimes, a financial autarky regime in the pre-liberalization era (i.e. before 1991) and a complete markets regime in the postliberalization period (i.e. after 1991). Specifically, we estimate for both the US and

\footnotetext{
${ }^{2}$ Source: IMF, World Economic Outlook.
} 
China ERP, risk-free rate, RER volatility-consumption volatility ratio, correlation between RER and consumption differentials, cross-country consumption correlation over two different sub-samples: i) pre-liberalisation era (i.e. 1972-1990); ii) postliberalisation era (i.e 1991-2009). International macroeconomic quantities and prices are then computed by assuming two different international capital market structures.

Complete markets are almost invariably assumed in international finance and IBC studies (Colacito and Croce, 2010; Ready et al., 2013, among others). Such environment is supported by recent studies showing that risk-sharing via financial markets is nearly optimal, and that trade frictions in goods markets are not negligible (Fitzgerald, 2012). However, the debate on whether emerging markets are fully integrated is still open. A large number of studies show that the post-9/11 era has been characterized by a steep increase in the level of financial integration across emerging and developed markets (Pukthuanthong and Roll, 2009; Bekaert et al., 2011; Volosovych, 2011; Donadelli, 2013; among others). For example, Ma and McCauley (2013) measure the de facto capital account openness for China and India. They show that both economies are becoming more financially open over time $3^{3}$ Evidence of a sharp increase in the level of financial integration in China can be found also in Cheung et al. (2006) and Lane and Schmukler (2007). According to this evidence, a full financial risk-sharing environment in the post-liberalisations era might represent a realistic US-China capital markets scenario $4^{4}$ Anyhow, in line with recent studies (see Tretvoll, 2008; Bacchetta and van Wincoop, 2013; Ready et al., 2013), we introduce partial risk-sharing by means of good markets frictions (consistently with the empirical evidence).

\footnotetext{
${ }^{3}$ International data confirm that financial and trade openness in China has largely increased in the mid 1990s (see the following measures: i) China's foreign trade with related counties and territories; ii) amount of foreign capital actually used by country or territory, freely available at http://www.stats.gov.cn/english/)

${ }^{4}$ We stress that existing empirical studies showing partial risk-sharing across emerging capital markets employ mostly pre-2000 data (Kose et al., 2007; Fitzgerald, 2012).
} 


\section{$2.2 \quad$ US-China stylized facts}

Figure 1 suggests that these two countries substantially increased their degree of openness toward international markets after 1990, and that their currencies' fluctuations largely increased after capital market liberalisations. This is clear from the dynamics of the ratios of the sum of US and China trade to world trade and the sum of US-owned assets abroad and foreign-owned assets in the US to the sum of US and China's GDPs. Both measures are increasing over time (Figure 1, top-left panel). We would argue that the increasing degree of integration across both equity and goods markets (Figure 1, top-left panel) $)^{5}$ has also largely influenced the RER volatility-consumption volatility ratio and the Backus-Smith correlation. The former has largely increased (Figure 1, top-right panel), whereas the latter has significantly decreased (Figure 1, bottom-left panel). The ratio between the RER and consumption volatility is constantly above one. Over the post-liberalizations period the average is 5.2 , a much higher value than that produced by standard IBC models. The correlation between RER and real consumption growth differentials declined sharply immediately after 1990 and started to become negative in the mid 90's (Figure 1, bottom-left panel). It particular, it is positive under financial autarky (i.e. 0.34 over the period 1972-1990), and negative after equity market liberalisations (i.e. -0.56 over the period 1991-2009) ${ }^{6}$ At odds with the results of a standard IBC model with complete markets, the correlation between the US and China real consumption growth rates is consistently far from unity (Figure 1, bottom-right panel).

\footnotetext{
${ }^{5}$ The current account-GDP ratio follows a similar dynamics.

${ }^{6} \mathrm{~A}$ similar results is obtained by Colacito and Croce (2013) on US-UK data.
} 

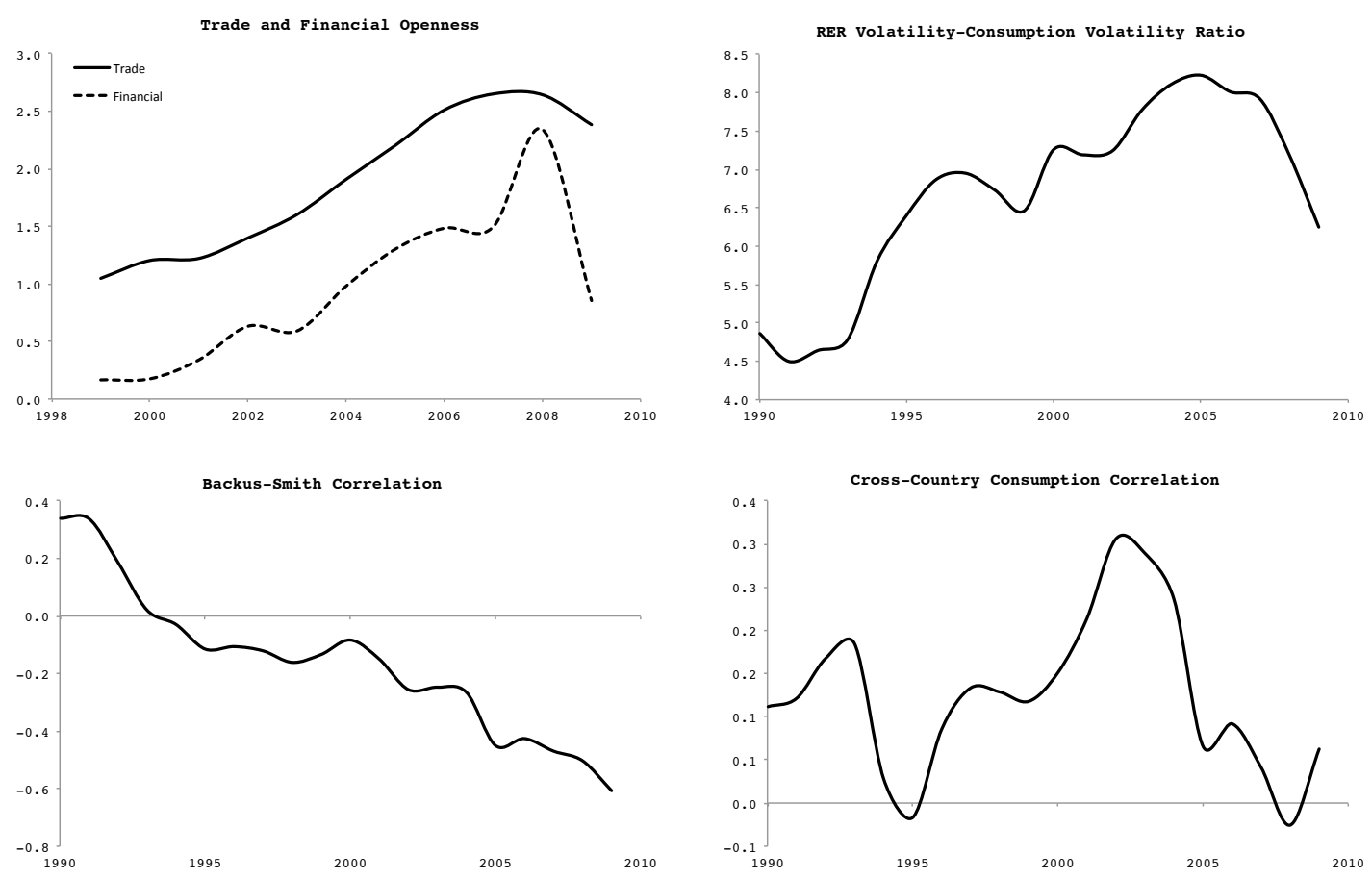

Figure 1: Financial and trade openness vs. puzzles. Notes: The trade openness is the ratio between sum of US-China imports and exports and sum of US and China GDPs. Financial openness is measured as the ratio between sum of U.S.-owned assets abroad and Foreign-owned assets in the United States and sum of US and China GDPs. The ratio between real exchange rate (RER) volatility and consumption growth volatility, the correlation between the real exchange rate and consumption differentials and the cross-country consumption correlation are computed using a rolling window of 20 years. Details on data sources are given in the appendix.

\section{The model: A Review}

\section{A. Consumption aggregate.}

The economy comprised two countries, home $(H)$ and foreign $(F)$, and two goods $G_{h}$ and $G_{f}$. The home (foreign) country is endowed with good $G_{H}\left(G_{F}\right)$. The agents' preferences are defined over a consumption aggregate of good $G_{H}$ and good $G_{H}$. Formally,

$$
\begin{aligned}
& C_{h, t}=\left(g_{h, t}^{h}\right)^{\alpha}\left(g_{f, t}^{h}\right)^{1-\alpha} \\
& C_{f, t}=\left(g_{h, t}^{f}\right)^{1-\alpha}\left(g_{f, t}^{f}\right)^{\alpha}
\end{aligned}
$$

where $C_{h, t}\left(C_{f, t}\right)$ is the consumption aggregate in the home (foreign) country, $g_{h, t}^{h}$ $\left(g_{h, t}^{f}\right)$ and $g_{f, t}^{h}\left(g_{f, t}^{f}\right)$ denote the consumption of good $G_{h}$ and good $G_{f}$ in the home 
(foreign) country at time $t$, and $\alpha \in(0,1)$ represents the home bias parameter.

\section{B. Preferences.}

\section{B.1 Standard preferences}

In the first part of our analysis preferences are represented by the power utility function. Formally,

$$
\begin{aligned}
U_{h, t} & =\frac{C_{h, t}^{1-\gamma}-1}{1-\gamma} \\
U_{f, t} & =\frac{C_{f, t}^{1-\gamma}-1}{1-\gamma}
\end{aligned}
$$

where $\gamma$ is the RRA coefficient.

\section{B.2 Recursive preferences}

Recursive Epstein and Zin (1989) preferences are as follows

$$
\begin{aligned}
U_{h, t} & =\left[(1-\delta)\left(C_{h, t}\right)^{\frac{1-\gamma}{\theta}}+\delta E_{t}\left[\left(U_{h, t+1}\right)^{(1-\gamma)}\right]^{\frac{1}{\theta}}\right]^{\frac{\theta}{1-\gamma}} \\
U_{f, t} & =\left[(1-\delta)\left(C_{f, t}\right)^{\frac{1-\gamma}{\theta}}+\delta E_{t}\left[\left(U_{f, t+1}\right)^{(1-\gamma)}\right]^{\frac{1}{\theta}}\right]^{\frac{\theta}{1-\gamma}}
\end{aligned}
$$

where $0<\delta<1$ is the subjective discount factor and $\delta^{-1}-1$ the rate of time preference, $\gamma>0$ is the risk aversion parameter, $\theta=\frac{1-\gamma}{1-1 / \psi}$, and $\psi$ is the intertemporal elasticity of substitution. In this setup, agents care about future uncertainty if $\gamma-1 / \psi>0$.

\section{B. Endowments.}

Endowments are cointegrated processes and embody a long-run risk component. Formally,

$$
\begin{aligned}
& \Delta \log G_{h, t}=\mu+\omega_{h, t-1}+\tau\left(\log G_{f, t-1}-\log G_{h, t-1}\right)+\epsilon_{h, t}^{S R} \\
& \Delta \log G_{f, t}=\mu+\omega_{f, t-1}+\tau\left(\log G_{h, t-1}-\log G_{f, t-1}\right)+\epsilon_{f, t}^{S R}
\end{aligned}
$$




$$
\begin{aligned}
& \omega_{h, t}=\rho_{h} \omega_{h, t-1}+\epsilon_{h, t}^{L R} \\
& \omega_{f, t}=\rho_{f} \omega_{f, t-1}+\epsilon_{f, t}^{L R} .
\end{aligned}
$$

where $\mu$ is the long-run endowment growth rate, $\tau \in(0,1)$ denotes the co-integration parameter, $\omega_{h, t}$ and $\omega_{f, t}$ are highly persistent $\operatorname{AR}(1)$ processes, $\epsilon_{h, t}^{S R}$ and $\epsilon_{f, t}^{S R}$ are shortrun shocks, and $\epsilon_{h, t}^{L R}$ and $\epsilon_{f, t}^{L R}$ are long-run shocks. Shocks are distributed as follows

$$
\underbrace{\left(\begin{array}{c}
\epsilon_{h, t}^{S R} \\
\epsilon_{f, t}^{S R} \\
\epsilon_{h, t}^{L R} \\
\epsilon_{f, t}^{L R}
\end{array}\right)}_{\Xi} \sim \text { i.i.d. } N(\underbrace{\left(\begin{array}{c}
0 \\
0 \\
0 \\
0
\end{array}\right)}_{\mathbf{0}}, \underbrace{\left(\begin{array}{cccc}
\sigma_{\epsilon_{h}^{S R}}^{2} & \sigma_{\epsilon_{h}^{S R}, \epsilon_{f}^{S R}} & 0 & 0 \\
\sigma_{\epsilon_{f}^{S R}, \epsilon_{h}^{S R}} & \sigma_{\epsilon_{f}^{S R}}^{2} & 0 & 0 \\
0 & 0 & \sigma_{\epsilon_{h}^{L R}}^{2} & \sigma_{\epsilon_{h}^{L R}, \epsilon_{f}^{L R}} \\
0 & 0 & \sigma_{\epsilon_{f}^{L R}, \epsilon_{h}^{L R}} & \sigma_{\epsilon_{f}^{L R}}^{2}
\end{array}\right)}_{\Omega})
$$

where $\Xi$ is the shock vector and $\Omega$ is the variance-covariance matrix of the crosscountry short- and long-run shocks.

\section{Capital market structure and optimal allocations.}

\section{C.1 Financial Autarky}

As suggested by Cole and Obstfeld (1991), in a financial autarky regime trade in the goods market takes place and it must be balanced in every period. Formally, the budget constraint for the home and foreign country is

$$
\begin{array}{r}
g_{h, t}^{h}+p_{t} g_{f, t}^{h}=G_{h, t} \\
g_{h, t}^{f}+p_{t} g_{f, t}^{f}=p_{t} G_{y, t}
\end{array}
$$

Under financial autarky agents cannot trade securities internationally. In practice, markets are complete only domestically. Therefore, there is no room for international 
consumption smoothing. This capital market structure gives rise to the following optimal allocation

$$
\begin{gathered}
g_{h, t}^{h}=\alpha G_{h, t}, \quad g_{h, t}^{f}=(1-\alpha) G_{h, t} \\
g_{f, t}^{h}=(1-\alpha) G_{f, t}, \quad g_{f, t}^{f}=\alpha G_{f, t}
\end{gathered}
$$

In this setup, the real exchange rate is simply represented by the home-bias adjusted current relatively supply of the home and foreign goods. Formally,

$$
\Delta e_{t}=(2 \alpha-1)\left(\Delta G_{h, t}-\Delta G_{f, t}\right)
$$

\section{C.2 Complete markets}

In order to emphasize that the resolution of the puzzles does not rely on any financial market imperfections, we consider also complete and frictionless markets (i.e. full risk-sharing). Consumption allocations under complete markets represent a standard benchmark in the recent international finance literature, especially when developed countries are considered. However, after stock market liberalizations the amount of risk-sharing via capital markets among developed and emerging countries has also largely increased (Donadelli, 2013; Ma and McCauley, 2013; Suzuki, 2014).

Under market completeness the following home and foreign budget constraints holds:

$$
\begin{gathered}
g_{h, t}^{h}+p_{t} g_{f, t}^{h}+\sum_{s_{t+1}} P_{t+1}\left(s^{t+1}\right) A_{h, t+1}\left(s^{t+1}\right) \leq G_{h, t}+A_{h, t} \\
g_{h, t}^{f}+p_{t} g_{f, t}^{f}+\sum_{s_{t+1}} P_{t+1}\left(s^{t+1}\right) A_{f, t+1}\left(s^{t+1}\right) \leq p_{t} G_{f, t}+A_{f, t}
\end{gathered}
$$

where $p_{t}$ is the price of good $G_{f, t}$ in terms of $\operatorname{good} G_{h, t}, A_{h, t}\left(s^{t}\right)\left(A_{f, t}\left(s^{t}\right)\right)$ denotes the claim of country home (foreign) to time $t$ consumption of good $G_{h, t}$, and $P_{t+1}$ is the state-contingent price (i.e. the price of one unit of $t+1$ consumption contingent 
on the realization of $s^{t+1}$ at time $\left.t+1\right)$. In equilibrium, the following holds:

$$
A_{h, t}+A_{f, t}=0, \quad \forall t
$$

. The efficient allocation is the solution of a planner's problem choosing a sequence of allocations $\left\{g_{h, t}^{h}, g_{h, t}^{f}, g_{f, t}^{h}, g_{f, t}^{f}\right\}_{t=0}^{+\infty}$ to maximize

$$
Q=W_{h} U_{h, 0}+W_{f} U_{f, 0}
$$

subject to the following feasibility constraints:

$$
g_{h, t}^{h}+g_{h, t}^{f}=G_{h, t} ; \quad g_{f, t}^{h}+g_{f, t}^{f}=G_{f, t} \quad \forall t \geq 0
$$

where $W_{h}$ and $W_{f}$ are the date $t=0$ non-negative Pareto weights attached to the consumer by the planner. By assuming $S_{t}=W_{h, t} / W_{f, t}$, the first order conditions of the social planning problem give rise to the following Pareto optimal allocation ${ }^{7}$

$$
\begin{gathered}
g_{h, t}^{h}=\alpha G_{h, t}\left[1+\frac{(1-\alpha)\left(S_{t}-1\right)}{1-\alpha+\alpha S_{t}}\right], \quad g_{h, t}^{f}=(1-\alpha) G_{h, t}\left[1+\frac{\alpha\left(S_{t}-1\right)}{1-\alpha+\alpha S_{t}}\right] \\
g_{f, t}^{h}=(1-\alpha) G_{f, t}\left[1+\frac{\alpha\left(S_{t}-1\right)}{\alpha+(1-\alpha) S_{t}}\right], \quad g_{f, t}^{f}=\alpha G_{f, t}\left[1+\frac{(1-\alpha)\left(S_{t}-1\right)}{\alpha+(1-\alpha) S_{t}}\right]
\end{gathered}
$$

where

$$
S_{t}=S_{t-1} \frac{M_{h, t}}{M_{f, t}}\left(\frac{e^{\Delta c_{h, t}}}{e^{\Delta c_{f, t}}}\right)
$$

and $M_{h, t}\left(M_{f, t}\right)$ is the home (foreign) stochastic discount factor. Under complete markets changes in the real exchange rate are equal to the difference between the log of the foreign and domestic stochastic discount factors.

$$
\Delta e=\log M_{f, t}-\log M_{h, t}
$$

\section{E. The stochastic discount factor.}

\footnotetext{
${ }^{7}$ For details, see Croce and Colacito (2013).
} 


\section{E.1 Standard preferences}

CRRA preferences imply the following stochastic discount factor

$$
\begin{aligned}
& M_{h, t+1}=\delta\left(\frac{C_{h, t+1}}{C_{h, t}}\right)^{-\gamma} \\
& M_{f, t+1}=\delta\left(\frac{C_{f, t+1}}{C_{h, t}}\right)^{-\gamma}
\end{aligned}
$$

for the home and foreign country, respectively.

\section{E.2 Recursive preferences}

As shown in Epstein and Zin (1989), the stochastic discount factor in the home and foreign country takes the following form

$$
\begin{aligned}
& M_{h, t+1}=\delta\left(\frac{C_{h, t+1}}{C_{h, t}}\right)^{-(1 / \psi)}\left(\frac{U_{h, t+1}^{1-\gamma}}{E_{t}\left[U_{h, t+1}^{1-\gamma}\right]}\right)^{\frac{1}{\psi}-\gamma} \\
& M_{f, t+1}=\delta\left(\frac{C_{f, t+1}}{C_{f, t}}\right)^{-(1 / \psi)}\left(\frac{U_{f, t+1}^{1-\gamma}}{E_{t}\left[U_{f, t+1}^{1-\gamma}\right]}\right)^{\frac{\frac{1}{\psi}-\gamma}{1-\gamma}}
\end{aligned}
$$

\section{Calibration and results}

Recent IBC studies argue that international consumption and financial risk sharing is incomplete (Heathcote and Perri, 2002; Bodenstein, 2008; Corsetti et al., 2008, Devereux and Yetman, 2010; Kollman, 2012, among others). For this reason, canonical IBC models with complete markets do not address classic international macroeconomic puzzles. In addition, by assuming standard preferences and frictionless and complete markets they inherit all the puzzles of domestic asset pricing. In this section, we demonstrate that if agents have recursive preferences and cross-country long-run endowment innovations are positively correlated, market incompleteness is not necessary to address the three classic international macroeconomic puzzles. In this setup, we also address domestic asset pricing puzzles. However, if agent's 
preferences are represented by power utility, the presence of complete markets only allows for the resolution of the RER volatility puzzle.

\subsection{Benchmark calibration}

The calibration of the endowment processes' components (i.e. $\tau, \sigma_{\epsilon}^{S R}, \sigma_{\epsilon}^{L R}$, $\left.\rho_{\epsilon_{h}^{L R} \epsilon_{f}^{L R}}, \rho_{\epsilon_{h}^{S R} \epsilon_{f}^{S R}}\right)$ is based on Colacito and Croce $(2010,2013)$. The parameter values are aimed at capturing a period of increasing financial and economic integration across two advanced economies. The consumption home bias parameter is equal to 0.97, suggesting that agents in the domestic country consume only $3 \%$ of foreign goods (i.e. $3 \%$ of total consumption is represented by imported goods). Given the observed growth in international trade since the 80's this value might appear unrealistic. However, the average ratio of US imports from China between 19992009 is $2 \%$. It turns out that the choice of $\alpha=0.97$ fits our US-China world, and is line with the benchmark calibration of Colacito and Croce (2013). A moderate amount of consumption home bias can be found in Thoenissen (2011) and Corsetti et al. (2008), who introduce preferences towards domestic goods in a standard IBC model with incomplete markets. $8^{8}$ All the other parameters (i.e. $\left.\mu, \rho, \gamma, \psi\right)$ are calibrated following previous long-run risk studies (Bansal and Yaron, 2004). The level of IES ensures that stock prices rise with expected future consumption growth and fall with the volatility of consumption growth, while the level of RRA delivers high ERP. Because RRA is greater than the reciprocal of IES, the ERP is driven not only by covariances of equity returns with current consumption, as in the classic power-utility model of Mehra and Prescott (1985), but also by the covariances of equity returns with expected future consumption growth (Restoy and Weil, 2011).

\footnotetext{
${ }^{8}$ For a detailed discussion on the role of home-bias in consumption and equity in a IBC context, see Tretvoll (2008).
} 


\begin{tabular}{|c|c|c|c|c|}
\hline \multicolumn{2}{|c|}{ Parameter } & Value & Parameter & Value \\
\hline$\mu$ & Endowment long-run growth rate & $2.00 \%$ & $\alpha$ Consumption home-bias & 0.97 \\
\hline$\sigma_{\epsilon}^{L R}$ & shock volatility & $1.87 \%$ & $\tau$ Co-integration parameter & $0.05 \%$ \\
\hline$\sigma_{\epsilon}^{S R}$ & Short-run shock volatility & $4 \% \sigma$ & $\delta$ Subjective discount factor & 0.9825 \\
\hline$\rho$ & omponent persistence & 0.985 & $\gamma \mathrm{RRA}$ & 8 \\
\hline$\rho_{\epsilon_{h}^{L} \epsilon_{f}^{L} R}$ & Long-run shocks correlation & 0.90 & $\psi$ IES & 1.5 \\
\hline$\rho_{\epsilon_{h}^{S R} \epsilon_{f}^{S R}}$ & Short-run shocks correlation & 0.05 & & \\
\hline
\end{tabular}

Table 1: Benchmark calibration

\subsection{Results: Financial autarky vs. complete markets}

To compare the role of the novel risk sharing mechanism embodied in the model, we compare the results obtained in an international complete markets regime with those obtained under financial autarky. First, we present the results of the model with standard preferences and both long-run risk and no long-run risk. Second, we turn our attention to the model with recursive preferences 9

\subsubsection{Standard preferences}

It is well known that in presence of complete markets and a power utility function, the ratio of domestic and foreign consumption determines the real exchange rate between two countries. It turns out that the correlation between consumption differentials and the real exchange rate equals unity. In addition, market completeness tends to produce a high degree of co-movement between domestic and foreign consumption growth rates. As a result, the real exchange rate rarely moves. Standard IBC models, by assuming complete and frictionless domestic asset markets and standard preferences, do not account also for all the domestic asset pricing puzzles. In practice, a model with standard preferences, frictionless and complete domestic markets does not solve the risk-free rate and the EPP puzzles. The results of canonical IBC models are partially confirmed in Table 2, which reports data from the US and China for the pre- and post-liberalisations periods along with the results for the benchmark calibration for two different capital market structures (i.e. financial

\footnotetext{
${ }^{9}$ The system of equations is solved by employing the perturbation methods. We compute our policy functions using the dynare ++4.3 .3 package.
} 
autarky and complete markets), both in the presence and absence of long-run risk. As discussed in section 2, we find that the RER volatility is higher and the RERconsumption differentials correlation becomes negative in the post-liberalizations period. Under both international capital markets regimes the model with power utility generates a close to zero ERP and an extremely high risk-free rate (Mehra, 2003). The values in Table 2 suggest that in both regimes the Backus-Smith anomaly is not resolved. On the one hand, a financial autarky regime produces a lower crosscountry consumption correlation and a less volatile RER volatility than a complete markets regime. On the other hand, market completeness tends to generate higher pressure on the currency through the international borrowing and lending channel. This implies that the model with standard preferences and complete markets addresses the RER volatility puzzle. The results is in stark contrast to the findings of Heathcote and Perri (2002) and Bodenstein (2008). Under complete markets the production economy of Heathcote and Perri (2002) generates extremely low RER volatility. Similarly, the endowment economy of Bodenstein (2008) with complete markets produces a close to unity RER volatility-consumption volatility ratio. To sum up, in both regimes the results produced by the models with and without long-run risk respectively are almost identical.

\begin{tabular}{lcccccc}
\hline $\begin{array}{l}\text { Model } \\
\text { CRRA }\end{array}$ & $\begin{array}{c}\text { Data } \\
\text { (pre-lib) }\end{array}$ & $\begin{array}{c}\text { Financial } \\
\text { Autarky } \\
\text { (no LRR) }\end{array}$ & $\begin{array}{c}\text { Financial } \\
\text { Autarky } \\
\text { (with LRR) }\end{array}$ & $\begin{array}{c}\text { Data } \\
\text { (post-lib) }\end{array}$ & $\begin{array}{c}\text { Complete } \\
\text { Markets } \\
\text { (no LRR) }\end{array}$ & $\begin{array}{c}\text { Complete } \\
\text { Markets } \\
\text { (with LRR) }\end{array}$ \\
\hline Key Stat & 4.357 & 0.248 & -0.207 & 7.542 & 0.190 & -0.281 \\
ERP & 1.458 & 16.686 & 15.921 & 0.999 & 16.850 & 16.078 \\
$E\left(R^{f}\right)$ & 4.869 & 1.115 & 1.128 & 5.259 & 5.276 & 5.094 \\
$\sigma(\Delta e) / \sigma(\Delta c)$ & 0.112 & 0.404 & 0.392 & 0.016 & 0.784 & 0.799 \\
$\operatorname{Corr}\left(\Delta c_{h}, \Delta c_{f}\right)$ & 0.338 & 1.000 & 1.000 & -0.557 & 1.000 & 1.000 \\
$\operatorname{Corr}\left(\Delta c_{h}-\Delta c_{f}, \Delta e\right)$ & & & &
\end{tabular}

Table 2: MODEL VS. DATA: MACROECONOMIC QUANTITIES AND PRICES. Notes: This table reports the average equity premium, $E R P$, risk-free rate, $E\left(R^{f}\right)$, real exchange rate volatility-consumption growth volatility puzzle, $\sigma(\Delta e) / \sigma(\Delta c)$, the cross-country consumption growth correlation, $\operatorname{Corr}\left(\Delta c_{h}, \Delta c_{f}\right)$, and the Backus-Smith correlation, $\operatorname{Corr}\left(\Delta c_{h}-\Delta c_{f}, \Delta e\right)$, simulated under different international capital market structures. All parameters are calibrated to the values reported in Table1. With no-LRR the long-run shock volatility and the cross-country long-run shock correlations are re-calibrated, $\sigma_{\epsilon}^{L R}=0$ and $\rho_{\epsilon_{h}^{S R} \epsilon_{f}^{S R}}=0.35$. Moments are calculated as the average over 200 simulations of 300 periods. The ERP and $R^{f}$ annualized and expressed in percentage points. The pre-liberalisations period runs from 1972 to 1990 . Details on data sources are given in the appendix. The post-liberalisations period runs from 1991 to 2009. 


\subsubsection{Recursive preferences}

As is well known, recursive preferences allow to separate the RRA parameter from the IES. Such separability is a necessary condition to match asset pricing data (Bansal and Yaron, 2004; Croce, 2012; Pancrazi, 2013). Table 3 reports data on the US and China for the pre- and post-liberalisations periods along with the key moments produced by the model with recursive preferences for the benchmark calibration for two different capital market structures (i.e. financial autarky and complete markets), both with and without long-run risk.

\begin{tabular}{lcccccc}
\hline $\begin{array}{l}\text { Model } \\
\text { EZ }\end{array}$ & $\begin{array}{c}\text { Data } \\
\text { (pre-lib) }\end{array}$ & $\begin{array}{c}\text { Financial } \\
\text { Autarky } \\
\text { (no LRR) }\end{array}$ & $\begin{array}{c}\text { Financial } \\
\text { Autarky } \\
\text { (with LRR) }\end{array}$ & $\begin{array}{c}\text { Data } \\
\text { (post-lib) }\end{array}$ & $\begin{array}{c}\text { Complete } \\
\text { Markets } \\
\text { (no LRR) }\end{array}$ & $\begin{array}{c}\text { Complete } \\
\text { Markets } \\
\text { (with LRR) }\end{array}$ \\
\hline Key Stat & & & & & & \\
ERP & 4.357 & 0.237 & 2.610 & 7.542 & 0.189 & 2.470 \\
$E\left(R^{f}\right)$ & 1.458 & 2.892 & 1.646 & 0.999 & 2.926 & 1.747 \\
$\sigma(\Delta e) / \sigma(\Delta c)$ & 4.869 & 1.115 & 1.128 & 5.259 & 5.112 & 7.595 \\
$\operatorname{Corr}\left(\Delta c_{h}, \Delta c_{f}\right)$ & 0.112 & 0.404 & 0.392 & 0.016 & 0.768 & 0.578 \\
$\operatorname{Corr}\left(\Delta c_{h}-\Delta c_{f}, \Delta e\right)$ & 0.338 & 1.000 & 1.000 & -0.557 & 1.000 & -0.145 \\
\hline
\end{tabular}

Table 3: MODEL VS. DATA: MACROECONOMIC QUANTITIES AND PRICES. Notes: This table reports the average equity premium, $E R P$, risk-free rate, $R^{f}$, real exchange rate volatility-consumption growth volatility puzzle, $\sigma(\Delta e) / \sigma(\Delta c)$, the cross-country consumption growth correlation, $\operatorname{Corr}\left(\Delta c_{h}, \Delta c_{f}\right)$, and the Backus-Smith correlation, $\operatorname{Corr}\left(\Delta c_{h}-\Delta c_{f}, \Delta e\right)$, simulated under different international capital market structures. All parameters are calibrated to the values reported in Table 1. With no-LRR the long-run shock volatility and the crosscountry long-run shock correlations are re-calibrated, $\sigma_{\epsilon}^{L R}=0$ and $\rho_{\epsilon_{h}^{S R} \epsilon_{f}^{S R}}=0.35$. Moments are calculated as the average over 200 simulations of 300 periods. The $E R P$ and $E\left(R^{f}\right)$ are annualized and expressed in percentage points. The pre-liberalisations period runs from 1972 to 1990. The post-liberalisations period runs from 1991 to 2009. Details on data sources are given in the appendix.

On the one hand, similarly to the economy with standard preferences, under financial autarky the RER volatility-consumption volatility ratio is close to one whereas in the data it is close to five. In addition, the correlation between the RER and consumption differential equals unity both in the model with and without long-run risk. Under financial autarky resources do not flow from the low-marginal utility country to the high-marginal utility one for consumption smoothing purposes. In practice, following positive long-run news regarding the supply of the domestic goods, agents in the home country have no access to international financial markets in order to buy insurance assets, and, therefore, give up part of their resources. This implies that, under financial autarky, foreign consumption does not move from $t+1$ 
onward and domestic consumption moves symmetrically with the RER (see Figure 2). On the other hand, in contrast to the economy with standard preferences, the model produces a sizable ERP and a relatively low risk-free rate (consistent with asset pricing data). The inclusion of complete markets in the model without long-run risk only affects the RER volatility which is more than five times the consumption volatility (consistently with post-liberalization data).
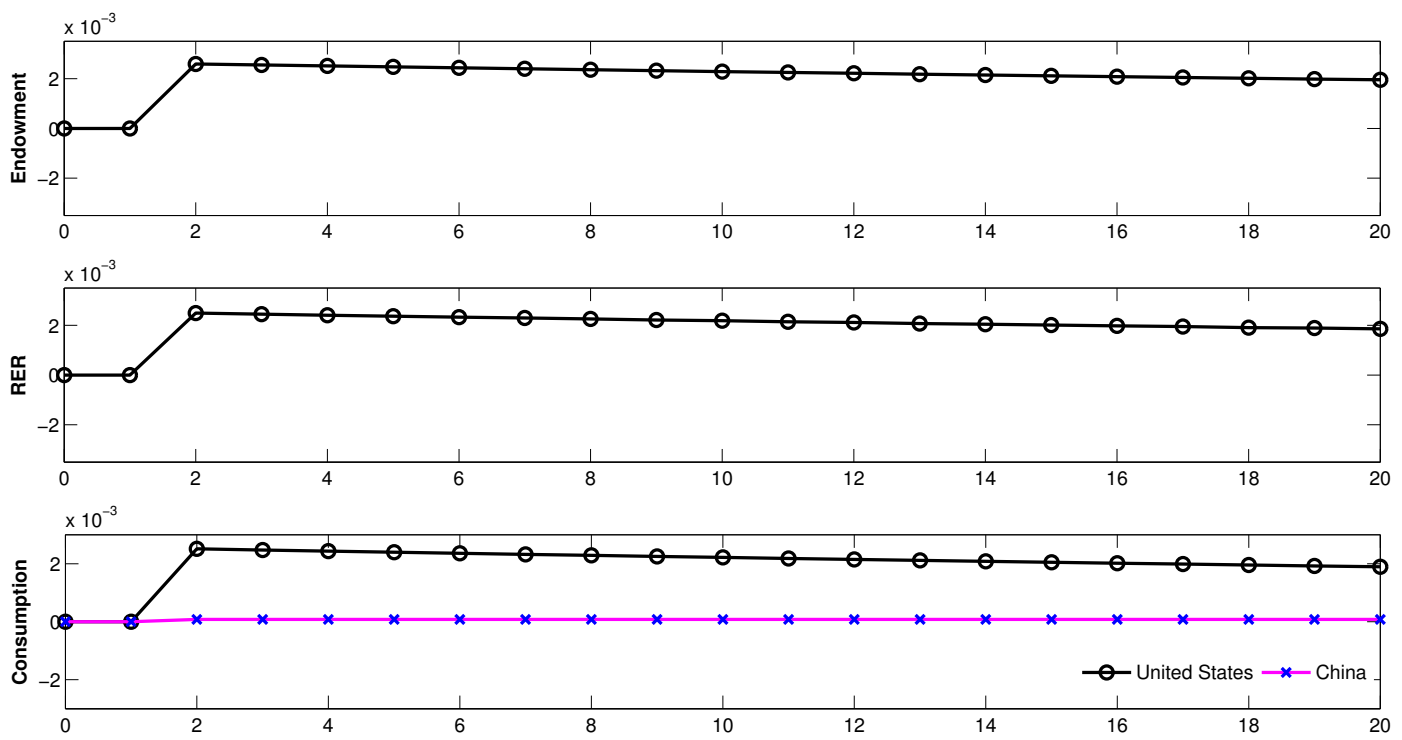

Figure 2: Impulse response functions: Financial Autarky. Notes: This figure shows the impulse response functions of endowment, exchange rate and domestic (black line) and foreign (pink line) consumption to a long-run positive news to the supply of the domestic goods.

By contrast, the novel risk sharing mechanism embodied in the two country-two good model with recursive preferences and complete markets produces endogenous time variation in the distribution of consumption and currency risk across countries. Therefore, the combination of recursive preferences, complete and frictionless markets, and long-run risk can simultaneously address the three international macroeconomic puzzles as well as the risk-free rate puzzle and the EPP. In this environment, risk-sharing takes place through imports and exports. In other words, endowments flow from the low-marginal utility country to the high-marginal utility one. For example, following positive long-run news on the supply of the domestic good, there is long-lasting impact on the domestic marginal utility. This implies 
that domestic agents will steadily decrease their share of world consumption (via exports) from time $t+1$ onward (as long-run news does not affect current consumption). It turns out that domestic consumption decreases and foreign consumption increases. Because of the excess supply of the domestic good, the RER depreciates. The last two effects are key to replicate the Backus-Smith anomaly. This is clear from Figure 3, which shows the impulse response functions of endowment, share of world consumption, RER and domestic and foreign consumption following long-run news on the supply of the home good. The relatively high RRA and IES values imply that agents are risk-averse. This means that they are willing to exchange part of their current resources for an insurance against variations in future utility. Therefore, in the presence of long-run news, domestic agents will reduce their share of world consumption to buy insurance assets in the financial markets. This mechanism generates a substantial amount of pressure on the currency and significantly affects asset prices. It turns out that the model with recursive preferences, complete markets and long-run risk produces a relatively high ERP, a relatively low risk-free rate and a relatively high RER volatility (see last column of Table 3 ) ${ }^{10}$

\subsection{A sensitivity analysis}

Table 4 reports sensitivity results for the RRA (first column), $\gamma$, the intertemporal elasticity of substitution (second column), $\psi$, consumption home bias (third column), $\alpha$, cross-country long-run shock correlation (fourth column), $\rho_{\epsilon_{h}^{L R} \epsilon_{f}^{L R}}$, and the subjective discount factor (fifth column), $\delta$. The last column of Table 4 reports the empirical moments for the post-liberalizations period (consistent with an international complete markets regime). The real exchange-rate volatility, the crosscountry consumption growth correlation and the Backus-Smith anomaly are weakly affected by different RRA and IES values. The subjective discount factor, the coefficient of risk aversion and the intertemporal elasticity of substitution represent

\footnotetext{
${ }^{10}$ In contrast to recent IBC studies (Devereux and Yetman, 2010; Devereux and Sutherland, 2011), this model produces also a non-close to unity cross-country equity markets return correlation.
} 

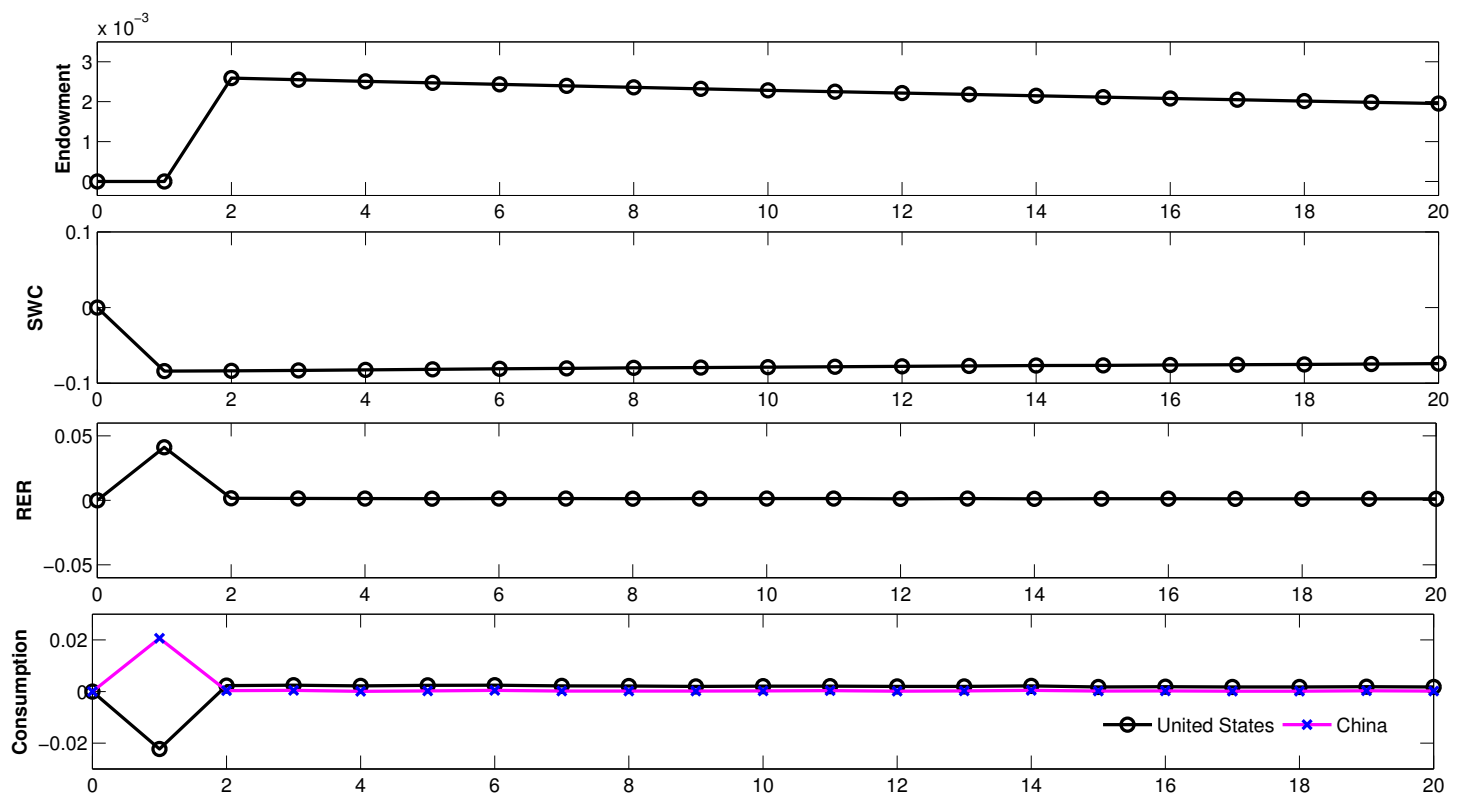

Figure 3: Impulse response functions: Complete Markets. Notes: This figure shows the impulse response functions of endowment, share of world consumption, exchange rate and domestic (black line) and foreign (pink line) consumption to a long-run positive news to the supply of the domestic goods.

risk-sharing based parameters. In practice, they control agent's willingness to share risk. This implies that changes in these parameters tend to affect mainly the agents' utility function but leave the set of feasible allocations unchanged. In other words, different values of $\beta, \gamma$ and $\psi$ alter the ERP and the risk-free rate. As is standard in the long-run risk literature (Bansal and Yaron, 2004; Pancrazi, 2013), a higher RRA or IES produces a higher ERP as well as a higher RER volatility-consumption volatility ratio. The explanation is straightforward. With higher RRA or IES values, agents become more risk averse to consumption and utility risk and their willingness to buy insurance assets (for consumption smoothing) increases. Therefore, asset prices change and the currency becomes much more volatile.

By assuming sufficiently impatient agents (i.e. $\delta=0.96$ ), the model is still able to produce a high RER volatility, a negative correlation between RER and consumption differentials, and a relatively low cross-country consumption correlation. These results are in line with those of Bodenstein (2008). However, in this model there is full financial risk-sharing whereas in the Bodenstein (2008)'s endowment 


\begin{tabular}{lccccc|c}
\hline $\begin{array}{l}\text { Model (with LRR) } \\
\text { Complete markets (EZ) }\end{array}$ & $\begin{array}{c}\text { Higher RRA } \\
\gamma=10\end{array}$ & $\begin{array}{c}\text { Higher IES } \\
\psi=2\end{array}$ & $\begin{array}{c}\text { Lower } \alpha \\
\alpha=0.9\end{array}$ & $\begin{array}{c}\text { Lower Corr } \\
\rho_{\epsilon_{h}^{L R} \epsilon_{f}^{L R}}=0.75\end{array}$ & $\begin{array}{c}\text { Lower } \delta \\
\delta=0.96\end{array}$ & $\begin{array}{c}\text { Data } \\
\text { (Post-Lib) }\end{array}$ \\
\hline Key Statistics & & & & & & \\
ERP & 3.153 & 4.760 & 2.434 & 2.305 & 0.76 & 7.542 \\
$E\left(R^{f}\right)$ & 1.408 & 0.700 & 1.773 & 1.843 & 4.91 & 0.999 \\
$\sigma(\Delta e) / \sigma(\Delta c)$ & 9.428 & 9.525 & 3.053 & 9.381 & 2.62 & 5.259 \\
$\operatorname{Corr}\left(\Delta c_{h}, \Delta c_{f}\right)$ & 0.510 & 0.631 & 0.484 & -0.012 & 0.69 & 0.016 \\
$\operatorname{Corr}\left(\Delta c_{h}-\Delta c_{f}, \Delta e\right)$ & -0.418 & -0.304 & -0.517 & -0.639 & -0.12 & -0.557 \\
\hline
\end{tabular}

Table 4: MODEL VS. DATA: A SENSITIVITY ANALYSIS ON MACROECONOMIC QUANTITIES AND PRICES. Notes: This table reports the equity premium, $E R P$, the risk-free rate, $E\left(R^{f}\right)$, real exchange rate volatility-consumption growth rate volatility puzzle, $\sigma(\Delta e) / \sigma(\Delta c)$, the cross-country consumption growth correlation, $\operatorname{Corr}\left(\Delta c_{h}, \Delta c_{f}\right)$, and the Backus-Smith correlation, $\operatorname{Corr}\left(\Delta c_{h}-\Delta c_{f}, \Delta e\right)$. The $E R P$ and $E\left(R^{f}\right)$ are annualized and expressed in percentage points. Moments are calculated as the average over 200 simulations of 300 periods. Details on data sources are given in the appendix.

economy financial markets are complete but the enforcement of international financial contracts is limited (i.e. agents cannot share risk efficiently). By contrast, if contract enforcement is not limited and agents are not impatient, the model behaves as a standard IBC model with complete markets, that is, it produces a RER volatility-consumption volatility ratio close to one, a higher cross-country consumption correlation, and the correlation between RER and relative consumption is equal to one. As in Bodenstein (2008), we find that a lower degree of economic integration (i.e lower consumption home bias - $\alpha$ closer to 0.5 ), leads to a decrease in the RER volatility, and to a higher (negative) correlation between the RER and consumption differentials compared to the benchmark calibration.

Overall, the entries in Table 4 suggest that the parameter spaces of $\gamma, \psi, \alpha$, $\rho_{\epsilon_{h}^{L R} \epsilon_{f}^{L R}}$ and $\delta$ allowing the model to solve the three classic international macroeconomic puzzles are relatively large. The model fails if the correlation between domestic and foreign long-run innovation is significantly lower than in the benchmark calibration, and succeeds for values up to $\rho_{\epsilon_{h}^{L R} \epsilon_{f}^{L R}}=0.75$. In this case, it produces a negative correlation between consumption growth rates, but still address the RER volatility and the Backus-Smith puzzle as well as the domestic asset pricing puzzles. It is noteworthy that it produces a negative correlation rather than a correlation close to unity (as in standard IBC models). Therefore, in our opinion, it "partially fails". This is in line with international consumption data over specific 
periods (see Figure 1, bottom-right panel). In addition, if the correlation between domestic and foreign long-run shocks ranges from 0.9 (benchmark calibration) to 0.76, the performance of the model is not affected, that is, it still solves the five puzzles simultaneously. This is clear from Figure 4, which plots the real exchange rate volatility-consumption volatility ratio, $\sigma(\Delta e) / \sigma(\Delta c)$, the correlation between the real exchange rate and consumption differentials, $\operatorname{Corr}\left(\Delta c_{h}-\Delta c_{f}, \Delta e\right)$, the crosscountry consumption growth correlation, $\operatorname{Corr}\left(\Delta c_{h}, \Delta c_{f}\right)$, for various values of the the cross-country long-run shocks correlation (on the horizontal axes), $\rho_{\epsilon_{h}^{L R} \epsilon_{f}^{L R}}$, by assuming $\alpha=0.97$ (Panel a) and $\alpha=0.9$ (Panel b) ${ }^{11}$

\footnotetext{
${ }^{11}$ It is also worth noting that the model produces a cross-country consumption correlation lower than an empirical cross-country GDP correlation (see dotted blue line in Figure 4). This holds if the parameter space of $\rho_{\epsilon_{h}^{L R} \epsilon_{f}^{L R}}$ is quite narrow.
} 

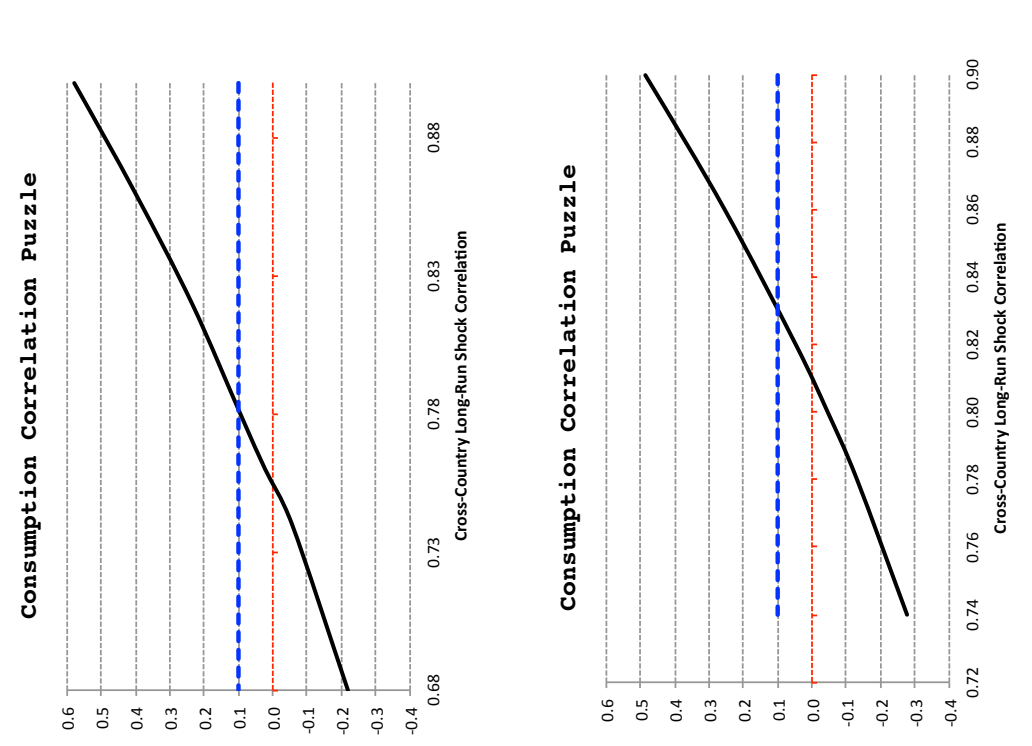

열 멸

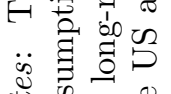

之े है

穴范

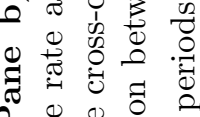

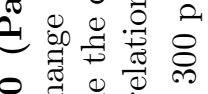

冬

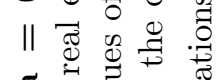

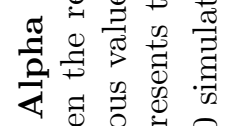

ส ๙
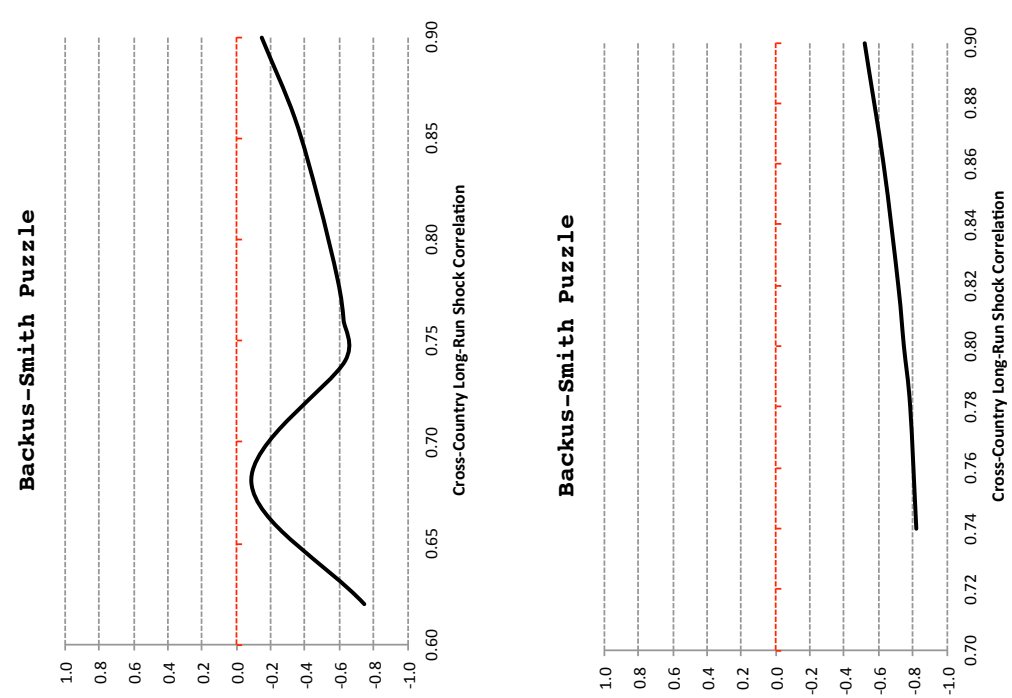

ब.

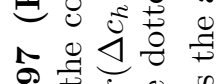
: $\|$ 过

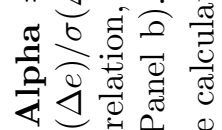
6 항

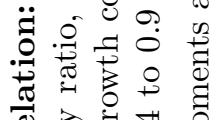
要

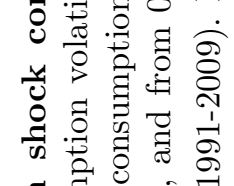

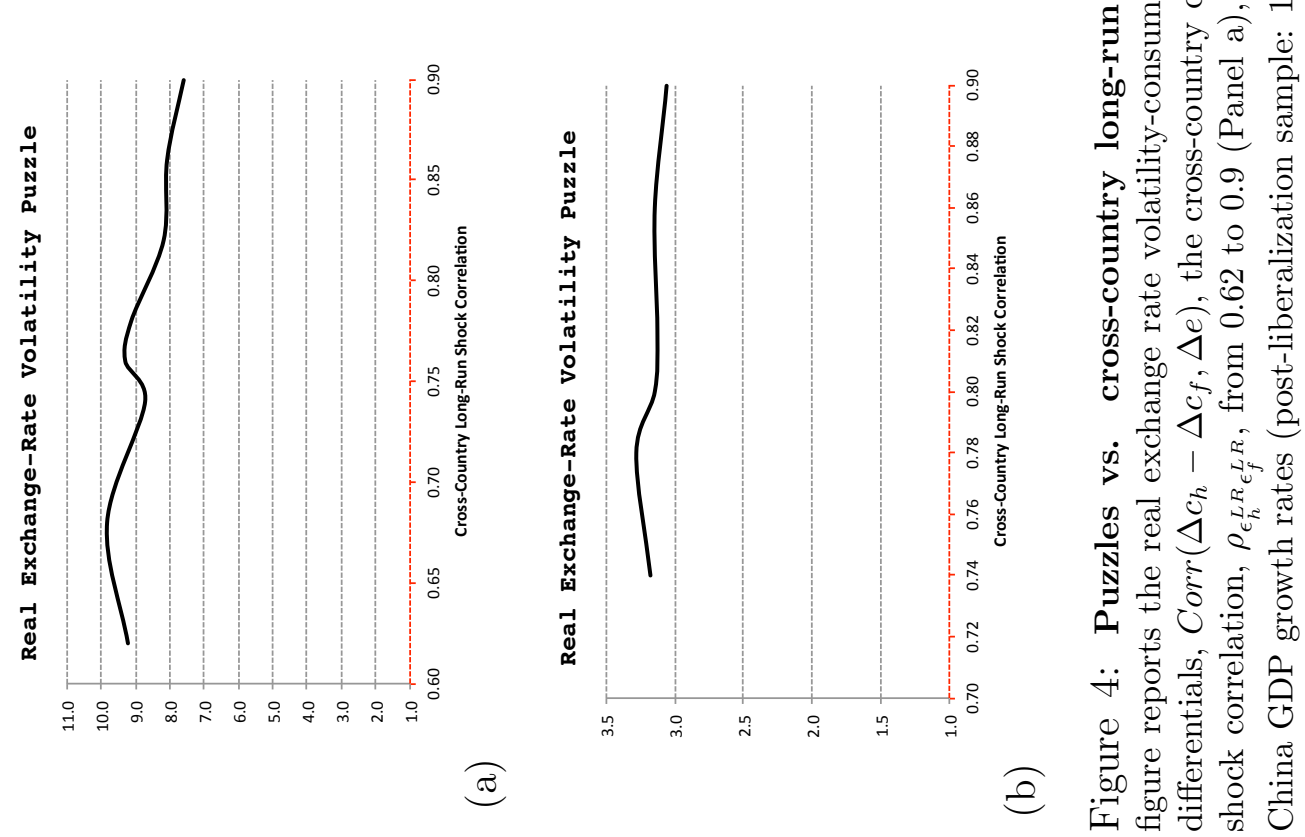




\section{Concluding remarks}

Early IBC studies show that a standard IBC model with complete markets does not account for the relatively high RER volatility, the negative correlation between RER and consumption differentials and the low cross-country consumption correlation in the data. They argue that such failure is due to the fact that market completeness produces an unrealistically high level of risk-sharing. Therefore, recent IBC studies argue that a lower degree of international risk-sharing represents a necessary condition to solve international macroeconomic puzzles. They rely on international complete markets regimes or financial market imperfections.

This paper compares the international quantities and prices generated under financial autarky (with standard and recursive preferences) with those under international complete markets (with standard and recursive preferences). The analysis is developed by using a two country-two good model with frictionless markets, highly correlated long run innovations and preferences towards domestic goods, and focuses on the US and China. In contrast to recent IBC studies, we show that a financial autarky regime does not represent a necessary condition to address international macroeconomic puzzles. Instead, under complete and frictionless markets, the combination of recursive preferences and long-run risk allows for the simultaneous resolution of three important international macroeconomic puzzles (i.e., RER volatility puzzle, Backus-Smith anomaly, consumption correlation puzzle) and two asset pricing puzzles (i.e., EPP and risk-free rate puzzle). In other words, in contrast to other studies, partial risk-sharing across international financial markets does not represent a necessary condition to solve the anomalies. The results are robust to relatively large changes in several parameter values. 


\section{References}

[1] Backus, D. K. and Smith, G., 1993. Consumption and real exchange rate in dynamic exchange economies with non traded goods. Journal of International Economics, 35, 297-316.

[2] Backus, D. K., Kehoe, P. J. and Kydland, F. E., 1994. Dynamics of the trade balance and terms of trade: the J-curve?. American Economic Review, 84, 84-103.

[3] Backus, D. K., Kehoe, P. J. and Kydland, F. E., 1995. International business cycles: theory and evidence. In: Cooley, T. (Ed.), Frontiers of Business Cycles Research. Princeton University Press, 331-356.

[4] Bansal, R. and Yaron, A., 2004. Risks for the long-run: A potential resolution of asset pricing puzzles. Journal of Finance, 59, 1481-1509.

[5] Bodenstein, M., 2008. International asset markets and real exchange rate volatility. Review of Economic Dynamics, 11, 688-705.

[6] Cheung, Y-W., Chinn, M. D. and Fujii, E. 2006. The Chinese economies in global context: The integration process and its determinants. Journal of the Japanese and International Economies, 20, 128-153.

[7] Colacito, R. and Croce, M., 2010. The short- and long-run benefits of financial integration. The American Economic Review, 100, 527-531.

[8] Colacito, R. and Croce, M., 2013. International asset pricing with recursive preferences. Journal of Finance, 68(6).

[9] Croce, M., 2012. Welfare costs and long-run consumption risk in a production economy. Mimeo.

[10] Corsetti, G., Dedola, L. and Leduc, S., 2008. International risk sharing and the transmission of productivity shocks. Review of Economic Studies, 75, 443-473. 
[11] Crucini, M., 1999. International and national dimensions of risk sharing. Review of Economics and Statistics, 81, 73-84.

[12] Devereux, M. B. and Yetman, J., 2010. Leverage constraints and international transmission of shocks. Journal of Money, Credit and Banking, 42(6), 71-105.

[13] Devereux, M. B. and Sutherland, A., 2011. Evaluating International Integration under Leverage Constraints. European Economic Review 55(3), 427-442.

[14] Donadelli, M. 2013. Global integration and emerging stock market excess returns. Macroeconomics and Finance in Emerging Market Economies, 6(2), 1-36.

[15] Epstein, L. G. and Zin, S. E., 1989. Substitution, risk aversion, and the temporal behavior of consumption and asset returns: A theoretical framework. Econometrica, $57(4), 93769$.

[16] Fitzgerald, D., 2012. Trade costs, asset market frictions, and risk sharing. American Economic Review 102, 2700-2733.

[17] Hamano, M., 2012. The consumption-real exchange rate anomaly with extensive margins. Journal of International Money and Finance, 36, 26-46.

[18] Heathcote, J. and Perri, F., 2002. Financial autarky and international business cycles. Journal of Monetary Economics, 49, 601-627.

[19] Jappelli, T. and Pistaferri, L., 2011. Financial integration and consumption smoothing. The Economic Journal, 121, 678-706.

[20] Kollmann, R. 2012. Limited asset market participation and the consumptionreal exchange rate anomaly. Canadian Journal of Economics, 45(2), 566-584.

[21] Kose, A. M., Prasad, E.S. and Terrones, M.E., 2007. How does financial globalization affect risk sharing? Patterns and channels. IMF Working Paper 07/238.

[22] Lane, P. R. and Schmukler, S. L., 2007.The international financial integration of China and India. World Bank Policy Research Working Paper 4132. 
[23] Lewis, K., 1996. What can explain the apparent lack of international consumption risk sharing?. Journal of Political Economy, 104, 267-297.

[24] Ma and McCauley, 2013. Is China or India more financially open? Journal of International Money and Finance, 39, 6-27.

[25] Mehra, R., 2003. The equity premium: Why is it a Puzzle?. Financial Analysts Journal, 54-69.

[26] Mehra, R. and Prescott, E. C., 1985. The equity premium: A puzzle. Journal of Monetary Economics 15(2), 145-161.

[27] Pancrazi, R., 2013. How beneficial was the great moderation after all? Mimeo.

[28] Pukthuanthong, K. and Roll, R., 2009. Global market integration: An alternative measure and its application. Journal of Financial Economics, 92(2), 214-232.

[29] Ready, R., Roussanov, N. and Wards, C., 2013. Commodity trade and the carry trade: A tale of two countries. Mimeo.

[30] Restoy, F. and Weil, P., 1998. Approximate equilibrium asset prices, NBER Working Paper 6611.

[31] Santos Monteiro, P., 2008. Testing full consumption insurance in the frequency domain. Mimeo.

[32] Suzuki, Y., 2014. Financial integration and consumption risk sharing and smoothing. International Review of Economics and Finance, 29, 585-598.

[33] Thoenissen, C., 2011. Exchange rate dynamics, asset market structure, and the role of trade elasticity. Macroeconomic Dynamics, 15, 119-143.

[34] Tretvoll, H., 2008. Home-bias in consumption and equities: can trade costs jointly explain both?. New York University, Working Paper. 
[35] Volosovych, V., 2011. Measuring financial market integration over the long run: Is there a U-shape?. Journal of International Money and Finance, 30, 1535-1561.

[36] Weil, P., 1989. The equity premium puzzle and the risk-free rate puzzle. Journal of Monetary Economics, 24 (3), 401-421. 


\section{A Data}

We base our analysis on US-China data over the period 1972-2009. Real consumption data are from the Robert Barro's website (Barro-Ursua Macroeconomic Data, 2010, freely available at http://rbarro.com/data-sets/). The annual average China/US nominal exchange rate, and the US and China GDP deflator are collected from the St. Louis FED (FRED ECONOMIC DATA, freely available at http://research.stlouisfed.org/fred2/). The US annual average equity risk premium and risk-free rate are from Kenneth French Data Library (freely available at http://mba.tuck.dartmouth.edu/pages/faculty/ken.french/data_library.html).

The Gross Domestic Product (GDP) of the US, China, UK, and Germany (at current US\$ prices) are from the IMF World Economic Outlook Databases (WEO). Data on international transactions are from Bureau of Economic Analysis (Table 12, U.S. International Transactions, by Area - China, freely available at http: //www.bea.gov/international/index.htm). We collect the following series: Exports of goods and services and income receipts (line 1), imports of goods and services and income payments (line 18), U.S.-owned assets abroad, excluding financial derivatives (line 40), foreign-owned assets in the United States, excluding financial derivatives (line 55). All series are available from 1999. 